\title{
Iron deficiency, an unfair inheritance
}

About 20 years ago, George R. Buchanan, a Professor of Pediatrics at the University of Texas, published an editorial titled The tragedy of iron deficiency during infancy and early childhood in The Journal of Pediatrics. ${ }^{1}$

In his article, Buchanan drew attention to nutritional anemia due to iron deficiency, which remained a prevalent condition. He considered it, citing colleagues from his country, as a "pediatric failure", and at the same time with disappointment and sadness because it was a preventable condition. He also mentioned that "tragedy" could have been considered a very strong term when compared to other diseases like cancer or severe congenital anomalies. According to Buchanan, iron deficiency is rarely fatal; however, it is a tragedy because of its effects on the brain due to irreversible injuries caused by improper nutritional practices. ${ }^{1}$

In Argentina, nutritional iron deficiency anemia is still a prevalent condition in children younger than 2 years. There are also other vulnerable age groups, including children younger than 6 years and pregnant and breastfeeding women, who are affected by a undesired prevalence of anemia. ${ }^{2,3}$ In some regions, mild to moderate nutritional anemia prevails, whose impact on child development is still unknown, while in other regions, anemia cases may be more severe.

The study by Zapata et al., published in this issue of Archivos Argentinos de Pediatria, is highly relevant. The information provided by the authors is necessary to deepen preventive measures in relation to health care and public health. Knowing iron and folate food sources is helpful to make decisions about the strategies to address an apparently simple problem but that, as demonstrated over time, cannot be solved. ${ }^{4}$

The development of that study with the support of the Child Nutrition Study Center (Centro de Estudio sobre Nutrición Infantil, CESNI) picked up on the center's commitment to this topic.

In 1992, Calvo et al., published a collaborative study between Maternidad Sardá and the CESNI. The study results indicated that the prevalence of iron deficiency and anemia in infants at 9 months old reached $27 \%$ among those who had been exclusively breastfed until 6 months old and suggested iron supplementation as of 4 months old. ${ }^{5}$
Also supported by the CESNI, in 1990, Calvo communicated a high prevalence of anemia $(46.7 \%)$ in children aged $9-24$ months, $46 \%$ of whom had at least 2 out of 3 biochemical indicators of iron deficiency.

Results were associated with an early introduction of whole cow's milk, a low intake of fortified food, and lack of iron supplementation. ${ }^{6}$

Then, in 1997, CESNI Director Alejandro O'Donnell and his collaborators published an interesting review about the results of the main studies on iron deficiency and anemia in infants, preschool children, women of childbearing potential, and pregnant women in Argentina. They also expressed their concerns about the lack of resolution of a problem that had existed for several years and described reasons that were similar to those indicated in previous studies for such high prevalence of iron deficiency and anemia in different population groups. ${ }^{7}$

Those outcomes in pregnant women and children younger than 2 years repeated or showed an even higher prevalence in subsequent studies done in 2002 and 2003 in the province of Chaco by Moraso et al., and in the province of Buenos Aires in an assessment of the impact of a food program in the 2003-2004 period, as published by Varea et al., and Malpelli et al. 3,8-11

Years later, the National Survey on Nutrition and Health of 2005, a milestone in the nutritional assessment of the Argentine population, showed a high anemia prevalence at a national level in different age groups. ${ }^{2}$ The numbers were alarming and no major changes from previous regional studies were observed.

In Argentina, wheat flour enrichment was established, as per Law no. 25630 in July 2002. On August 14 ${ }^{\text {th }}, 2003$, its Regulatory Decree (no. $597 / 03$ ) was finally published in the Official Bulletin. This was also considered a milestone in the fight against iron and folate deficiency.

Calvo demonstrated that flour fortification with folic acid was associated with adequate folate intake and serum levels among women.

She also observed a significant reduction in the prevalence of neural tube defects and related mortality. ${ }^{12}$

However, the results in relation to iron deficiency did not evolve in the same way.

The alarming diagnosis made by Bernztein and Drake in 2008 about iron under prescription 
at the first level of care was a major contribution to explain, at least partially, the persistence of this phenomenon; to date, there is no reliable information indicating any improvement. ${ }^{13}$

On the other side, we are aware of the importance of a timely cord clamping, even with studies done in our setting by Ceriani Cernadas et al., who showed that cord clamping at 3 minutes significantly increased ferritin levels at 6 months old. ${ }^{14}$ However, there is no information demonstrating that we are all committed to comply with the recommendation.

We cannot ignore the impact of poverty on the problem addressed in this editorial, and it is important to know the conditions for accessing the health system and the food safety indicators of the populations under analysis.

A strength of the study by Zapata et al., is that it approaches this topic from the perspective of the life cycle. That study included a closed survey, so breast milk was not shown as a source of iron in children younger than 2 years, but it included the source of iron for pregnant and breastfeeding women. Although iron from breast milk remains stable in different nutritional statuses, iron supplementation interventions demonstrated a significant increase in breast milk iron levels. ${ }^{15}$

Conceptually, the World Health Organization considers that mothers and infants make up a biological and social unit, sharing health-disease and malnutrition problems. ${ }^{16}$

Before conception, maternal health and nutritional status play an influential role on fetal and mammary gland development.

Nutritional stores in breastfeeding women may be more or less depleted as a result of pregnancy and blood loss during childbirth.

Breastfeeding entails special nutritional needs, basically due to the drainage of nutrients through breast milk. ${ }^{17}$

The life cycle is an approach that allows understanding the vulnerabilities and opportunities of interventions in the early stages of development; it shows that experiences occur over life, that the impact of interventions implemented in one generation will have an impact on future generations, and that the greatest benefit will result from previous interventions.

In addition, this approach improves the utilization of scarce resources by facilitating risk and gap identification and intervention prioritization.

Probably unintentionally, the study by Zapata et al. is an appeal to have a discussion about an ever-prevailing topic. They propose to know food sources and, at the same time, make us approach not only the isolated nutrient to study its deficiency, but also the concept of food and dietary patterns, as suggested by critical authors. ${ }^{18}$ Significant scientific information has been developed in our setting about such an intricate topic like nutritional anemia, which is transmitted in our population from one generation to the next as an unfair inheritance. There is something wrong with not being able to translate knowledge into effective interventions.

Horacio F. González, M.D.

Institute of Pediatric Development and Research (IDIP) "Prof. Dr. Fernando Viteri", Hospital de Niños de La Plata (Ministry of Health / Scientific Research Commission / Province of Buenos Aires

http:/ / dx.doi.org/10.5546/ aap.2020.eng.156

To cite: González HF. Iron deficiency, an unfair inheritance. Arch Argent Pediatr 2020;118(3):156-158.

\section{REFERENCES}

1. Buchanan GR. The tragedy of iron deficiency during infancy and early childhood. J Pediatr. 1999; 135(4):413-5.

2. Argentina. Ministerio de Salud. Encuesta Nacional de Nutrición y Salud. Documento de resultados2007. [Accessed on: February 21 ${ }^{\text {st }}$, 2020]. Available at: http://www.msal. gob.ar/images / stories / bes / graficos / $0000000257 \mathrm{cnt}$-a08ennys-documento-de-resultados-2007.pdf

3. Varea A, Malpeli A, Disalvo L, Apezteguía M, et al. Evaluation of the impact of a food program on the micronutrient nutritional status of Argentinean lactating mothers. Biol Trace Elem Res. 2012; 150(1-3):103-8.

4. Zapata ME, Rovirosa A, Carmuega E. Hierroy ácido fólico: Natural, enriquecido, fortificado y suplementos. Análisis de las fuentes alimentarias en la ciudad de Buenos Aires. Arch Argent Pediatr. 2020; 118(3): COMPLETAR

5. Calvo EB, Galindo AC, Aspres NB. Iron status in exclusively breast-fed infants. Pediatrics. 1992; 90(3):375-9.

6. Calvo EB, Gnazzo N. Prevalence of iron deficiency in children aged 9-24 mo from a large urban area of Argentina. Am J Clin Nutr. 1990; 52(3):534-40.

7. O’Donnell A M, Carmuega E, Durán P. Preventing Iron Deficiency in Infants and Preschool Children in Argentina. Nutr Rev. 1997; 55(6):189-94.

8. Morasso M del C, Molero J, Vinocur P, Acosta L, et al. Deficiencias de hierro y de vitamina A y prevalencia de anemia en niños y niñas de 6 a 24 meses de edad en Chaco, Argentina. Arch Latinoam Nutr. 2003; 53(1):21-7.

9. Morasso M del C, Molero J, Vinocur P, Acosta L, et al. Deficiencia de hierro y anemia en mujeres embarazadas en Chaco, Argentina. Arch Latinoam Nutr. 2002; 52(4):336-43.

10. Varea A, Malpeli A, Etchegoyen G, Vojkovic M, et al. Short-term evaluation of the impact of a food program on the micronutrient nutritional status of Argentinean children under the age of six. Biol Trace Elem Res. 2011; 143(3):1337-48. 
11. Malpeli A, Ferrari MG, Varea A, Falivene M, et al. Shortterm evaluation of theimpact of a fortified food aid program on the micronutrient nutritional status of Argentinian pregnant women. Biol Trace Elem Res. 2013; 155(2):176-83.

12. Calvo E, Biglieri A. Impacto de la fortificación con ácido fólico sobre el estado nutricional en mujeres y la prevalencia de defectos del tubo neural. Arch Argent Pediatr. 2008; 106(6):492-8.

13. Bernztein R, Drake I. Subprescripción de hierro y variabilidad en el primer nivel de atención público de la Argentina. Arch Argent Pediatr. 2008; 106(4):320-7.

14. Ceriani Cernadas JM, Carroli G, Pellegrini L, Ferreira M, et al. Efecto del clampeo demorado del cordón umbilical en la ferritina sérica a los seis meses de vida: Estudio clínico controlado aleatorizado Arch Argent Pediatr. 2010; 108(3):201-8.
15. Marin GH, Mestorino N, Errecalde J, Huber B, et al. Personalised iron supply for prophylaxis and treatment of pregnant women as a way to ensure normal iron levels in their breast milk. J Med Life. 2012; 5(1):29-32.

16. WHO, UNICEF. Global Strategy on infant and young child feeding. 2012. [Accessed on: February 21 ${ }^{\text {st }}, 2020$ ]. Available at: https: / / www.who.int/nutrition/publications / infantfeeding/9241562218/en/

17. Neville MC, Anderson SM, McManaman JL, Badger TM, et al. Lactation and neonatal nutrition: defining the critical questions. J Mammary Gland Biol Neoplasia. 2012; 17(2):16788.

18. Mozaffarian D, Rosenberg I, Uauy R. History of modern nutrition science-implications for current research, dietary guidelines, and food policy. BMJ. 2018; 361:k2392.

\section{Clinical and epidemiological study of acute lower respiratory tract infections caused by adenovirus in hospitalized children. Nineteen years of active epidemiological surveillance}

Acute respiratory tract infections are the main cause of morbidity in the pediatric population. Although the burden of disease is higher in low-resource areas, those with greater resource availability face the challenge of antibiotic resistance in bacterial infections and the identification of new pathogens. ${ }^{1,2}$

In recent years, the identification of respiratory viruses and their role in pneumonia in the pediatric population have increasingly progressed. Molecular techniques used for viral diagnosis help to detect up to $92 \%$ of respiratory viruses in children with pneumonia. Viruses associated with community-acquired pneumonia include human adenovirus (HAdV), human bocavirus $(\mathrm{HBoV})$, human coronavirus $(\mathrm{HCoV})$, enterovirus (EV), influenza virus (Flu), human metapneumovirus (hMPV), parainfluenza virus (PIV), and respiratory syncytial virus (RSV). ${ }^{3,4}$

The case-control study conducted by Rhedin et al., in Stockholm analyzed the association between respiratory viruses and pneumonia in children younger than 5 years and detected viruses in $98 / 121$ children with pneumonia $(81 \%)$ and in $134 / 240$ controls $(56 \%)$. The univariate analysis showed that the viruses significantly associated with communityacquired pneumonia were hMPV $(p<0.001)$, RSV $(p<0.001)$, Flu $(p=0.03)$, and HAdV $(p=0.05)$, whereas in the multivariate analysis HAdV did not show a significant relation to pneumonia and was quite common among controls. ${ }^{3}$ This may be due to the fact that, although adenovirus causes community-acquired pneumonia, it has been observed that it may remain in the lymphatic tissue in the tonsils for weeks. On the other side, there have also been reports of adenovirus latency in the lungs and reactivation in immunosuppressed hosts. ${ }^{5}$

Nascimento-Carvalho et al., found viruses in 708 children younger than 5 years old with pneumonia $(91.5 \%$; $95 \%$ confidence interval [CI]: 89.3-93.3); of them, 491 (69.4 \%; $95 \%$ CI: 65.972.7) were identified as having a viral coinfection. Rhinovirus (46.1\%; 95 \% CI: 42.6-49.6), adenovirus (38.4\%; $95 \%$ CI: 35.0-41.8), and enterovirus (26.5\%; $95 \%$ CI: 23.5-29.7) were the most common viruses, and the most frequent co-infection corresponded to rhinovirus and adenovirus. ${ }^{4}$

Although adenovirus was the less commonly respiratory virus identified through the entire period in the study of Bakir et al., ${ }^{6}$ published in this issue of Archivos, $4.4 \%(265 / 6047)$ of all positive cases, this may be due to the lower sensitivity and specificity of indirect immunofluorescence (IIF). On the other side, having included children with bronchiolitis may also have contributed to the lower detection ratio. As mentioned in the article, the most common clinical presentation was pneumonia.

The study by Yu Lin et al., reported a higher 